Media Informatika, Vol. 6, No. 1, Juni 2008, 71-84

ISSN: 0854-4743

\title{
EKSTRAKSI CIRI PADA ISYARAT SUARA JANTUNG MENGGUNAKAN POWER SPECTRAL DENSITY BERBASIS METODE WELCH
}

\author{
Yul Antonisfia ${ }^{1}$, Romi Wiryadinata ${ }^{2}$ \\ ${ }^{1}$ Staf Pengajar, Teknik Elektro Politeknik Negeri Padang, Sumatera Barat \\ ${ }^{2}$ Mahasiswa Sekolah Pascasarjana, Universitas Gadjah Mada, Jogjakarta \\ Website: http://wiryadinata.web.id; e-Mail: romi_wiryadinata@yahoo.com
}

\begin{abstract}
ABSTRAK
Telah dilakukan ekstraksi ciri data EKG untuk jantung murmur dan normal dengan mengklasifikasikan 24 isyarat murmur dan beberapa jantung normal. Perekaman menggunakan stetoskop dengan penguat berlebar bidang $1 \mathrm{kHz}$ direkam suara jantung normal dari beberapa orang sampel dan untuk melengkapi data murmur patalogis maka didownload suara murmur jantung dari situs internet. Isyarat suara jantung kemudian dianalisis spektral dayanya untuk diekstraksi ciri dan dicari beberapa resolusi spectral-nya. Hasil yang diperoleh menunjukan bahwa dengan ekstraksi ciri menggunakan metode spektral dapat membedakan suara jantung normal dan murmur. Keberhasilan isyarat yang bercampur derau dengan SNR 10 dB dapat mencapai 90\% dengan resolusi 125 cacah cuplikan frekuensi. Makin besar derau yang mempengaruhi isyarat suara jantung (SNR makin kecil) maka keberhasilan pengujian semakin mengecil.
\end{abstract}

Kata kunci: Ekstraksi Ciri, EKG, PSD Metode Welch

\section{PENDAHULUAN}

Serangan jantung masih menempati urutan pertama penyebab kematian dibanyak tempat di dunia. Gejala abnormalitas jantung (murmur) seringkali datang secara tiba-tiba, oleh karena itu pengenalan secara dini terhadap penyakit jantung dapat membantu untuk terhindar dari serangan jantung. Sampai saat ini dokter masih menggunakan isyarat suara jantung untuk memantau kinerja jantung dengan menggunakan stetoskop yang penggunaannya menghasilkan suara yang lemah, oleh sebab itu untuk mendiagnosis diperlukan kepekaan dan pengalaman, selain itu keterbatasan fisik juga sangat mempengaruhi hasil interpretasi hingga hasil diagnosis sangat dipengaruhi oleh subyektivitas dokter (Anonim, 2004).

Suara jantung yang didengar oleh dokter dengan menggunakan stetoskop sebenarnya terjadi pada saat penutupan katup. Kejadian ini dapat menimbulkan anggapan yang keliru bahwa suara tersebut disebabkan oleh penutupan daun katup tersebut, tetapi sebenarnya disebabkan oleh efek arus pusar (eddy) dalam darah akibat penutupan katup tersebut (Carr, 2001). Suara jantung normal mempunyai rentang frekuensi antara $20 \mathrm{~Hz}$ hingga $200 \mathrm{~Hz}$, sedangkan suara jantung abnormal mempunyai rentang frekuensi hingga $1000 \mathrm{~Hz}$. Salah satu jenis 
regurgitasi menyebabkan murmur dalam rentang 100 hingga $600 \mathrm{~Hz}$ dan bahkan untuk jenis murmur tertentu hingga $1000 \mathrm{~Hz}$ (Cromwell, 1980).

Pada penelitian ini ekstraksi ciri dilakukan dengan mencari rapat spektral daya (Power Spectral Density, PSD) dari isyarat suara jantung kemudian hasil berupa himpunan PSD nantinya dapat dilanjutkan pada penelitian berikutnya menggunakan beberapa metode dan algoritma kecerdasan buatan untuk pengenalan, klasifikasi, maupun proses lainnya, sehingga penelitian ini membatasi permasalahan untuk bagaimana mengklasifikasikan isyarat suara jantung dengan menggunakan metode PSD untuk ekstraksi ciri dengan menggunakan parameterparameter yang diantaranya adalah frekuensi, cacah cuplikan dan SNR.

Beberapa penelitian tentang isyarat suara jantung yang pernah dilakukan sebelumnya diantaranya adalah seperti yang dilakukan Widodo dan Soesanti pada tahun 2004 yang melakukan penelitian untuk merealisasikan sistem akuisisi, pengolahan, dan analisis isyarat suara jantung dengan metode spektral dan alihragam gelombang singkat. kemudian Widodo (2005) mengaplikasikan ANN (Articial Neural Network) untuk klasifikasi murmur jantung. Penelitian juga dilakukan oleh Jumnahdi pada tahun 2006 untuk mengklasifikasikan isyarat murmur jantung berbasis ANN metode LVQ (Learning Vector Quantization) dengan ekstraksi ciri menggunakan FFT (Fast Fourier Transform). Pada penelitian ini mencoba untuk mengekstraksi ciri isyarat murmur jantung dengan mencari rapat spektral daya.

Manfaat yang diharapkan dari penelitian ini adalah dapat membantu untuk mendeteksi dan mengklasifikasikan kelainan jantung setelah melalu proses ekstraksi ciri. Hasil dari penelitian ini diharapkan juga dapat bermanfaat bagi perkembangan ilmu pengetahuan dan teknologi khusunya pada bidang instrumentasi medis dengan memanfaatkan kolaborasi penelitian antara bidang kedokteran dengan bidang instrumentasi elektronis. Menurut batasan dari America College of Cardiologi, murmur adalah rangkaian panjang vibrasi suara yang bervariasi dalam intensitas, frekuensi, kualitas, konfigurasi dan lamanya.

Joewono (2003) menyatakan murmur disebabkan oleh adanya turbulensi Eddie's current dan pembentukan gelembung dalam sistem sistem sirkulasi. Widodo pada tahun 2005 pada penelitiannya mengatakan bahwa Articial Neural Network dapat membedakan dengan baik suara jantung normal dan beberapa murmur. Makin tinggi resolusi spektral isyarat maka keberhasilan klasifikasi semakin meningkat, sedangkan Efendi (2000) menganalisa isyarat EKG (Elektrokardiogram), mendeteksi dan membuat instrument monitoring abnormalitas isyarat EKG yang akan menghasilkan banyak atau macam-macam pola. Tahun 2002 Hasani telah menganalisis isyarat EKG yang digunakan untuk mendeteksi kondisi jantung pasien. Pada penelitiannya berbagai kondisi jantung yang merupakan isyarat elektronis disimpan dalam bentuk data sehingga pengelompokan dilakukan berdasarkan klasifikasi tersebut dan Jumnahdi (2006) mengklasifikasi isyarat murmur jantung yang pada penelitiannya menggunakan jaringan syaraf tiruan dengan LVQ (Learning Vector Quantization) dan ekstraksi ciri menggunakan FFT sebagai metode pengenalan untuk membedakan isyarat jantung normal, abnormal dan murmur. 


\section{DASAR TEORI}

\subsection{Jantung Sebagai Sumber Isyarat Bioelektris}

Jantung adalah organ muscular berlubang yang berfungsi sebagai pompa ganda sistem kardiovaskular. Sisi kanan jantung memompa darah ke paru sedangkan sisi kiri jantung memompa darah keseluruh tubuh. Berat jantung normal sekitar 1 pon $(0,45 \mathrm{~kg})$ atau sebesar tinju orang dewasa dan terletak didalam rongga dada diantara ruang dada (sternum kolumna vertebralis) (Atwood, 1996).

Jantung manusia terbagi menjadi dua bagian yaitu bagian kiri dan bagian kanan. Kedua bagian jantung ini dipisahkan oleh septum. Masing-masing bagian dibagi lagi menjadi dua ruangan yaitu serambi jantung (atria) yang terletak disebelah atas dan bilik jantung (ventricle) yang terletak disebelah bawah. Seperti yang terdapat pada (Gambar 1) dibawah ini, jantung mempunyai empat katup utama yang terbuat dari jaringan endokardium. Katup merupakan bangunan yang mirip penutup yang membuka dan menutup sebagai respon terhadap pemompaan jantung dengan membuka dan menutup katup memungkinkan darah bergerak keseluruh jantung, paru dan mencegah aliran darah kembali.

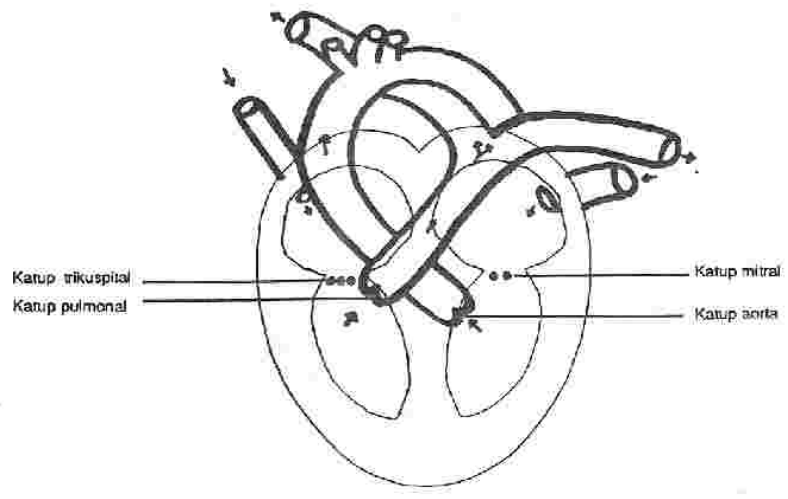

Gambar 1. Katup-katup Jantung

\section{$2.2 \quad$ Isyarat Suara Jantung}

Detak jantung menghasilkan 2 suara yang berbeda yang dapat didengarkan pada stetoskop yang sering dinyatakan dengan $l u b-d u b$. Suara lub disebabkan oleh penutupan katup tricuspid dan mitral (atrioventrikular) yang memungkinkan aliran darah dari serambi jantung (atria) ke bilik jantung (ventricle) dan mencegah aliran balik. Umumnya hal ini disebut suara jantung pertama (S1), yang terjadi hampir bersamaan dengan timbulnya QRS dari elektrokardiogram dan terjadi sebelum periode jantung berkontraksi (systole). Suara $d u b$ disebut suara jantung ke-dua (S2) dan disebabkan oleh penutupan katup semilunar (aortic dan pulmonary) yang membebaskan darah ke sistem sirkulasi paru-paru dan sistemik.

Katup ini tertutup pada akhir systole dan sebelum katup atrioventikular membuka kembali. Suara S2 ini terjadi hampir bersamaan dengan akhir gelombang $T$ dari EKG, suara jantung ke-tiga (S3) sesuai dengan berhentinya pengisian atrioventikular, sedangkan suara jantung ke-empat (S4) memiliki korelasi 
dengan kontraksi atria. Suara S4 ini memiliki amplitudo dan komponen frekuensi rendah seperti yang diperlihatkan pada Gambar 2.

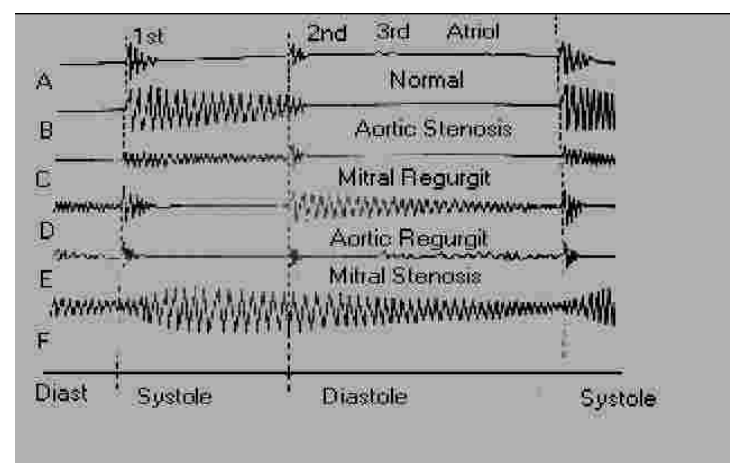

Gambar 2. Contoh grafik EKG (A: normal, B sampai F: Abnormal/murmur)

Jantung abnormal menghasilkan suara tambahan yang disebut murmur yang disebabkan oleh pembukaan katup yang tidak sempurna atau memaksa darah melewati bukaan sempit (stetonic) atau oleh regurgitasi yang disebabkan oleh penutupan katup yang tidak sempurna dan mengakibatkan aliran balik darah, dalam masing-masing kasus suara yang timbul adalah akibat aliran darah dengan kecepatan tinggi yang melewati bukaan sempit. Penyebab lain terjadinya murmur adalah adanya kebocoran septum yang memisahkan jantung bagian kiri dan kanan sehingga darah mengalir dari ventrikel kiri ke ventrikel kanan sehingga menyimpangkan sirkulasi sistemik (Anonim, 2004).

Gambar 2 bagian B sampai F menunjukan rekaman suara jantung abnormal dan beberapa contoh jenis murmur. Suara jantung normal mempunyai rentang frekuensi antar 20-200 Hz, sedangkan suara jantung abnormal mempunyai rentang frekuensi hingga $1000 \mathrm{~Hz}$. Suara jantung S1 terdiri atas energi dalam rentang frekuensi 30-45 Hz, yang sebagian besar berada dibawah ambang dengar. Suara jantung S2 biasanya memiliki nada lebih tinggi dengan energi maksimum berada dalam rentang 50-70 Hz. Suara jantung S3 merupakan vibrasi yang sangat lemah dengan hampir semua energinya dibawah $30 \mathrm{~Hz}$. Sedangkan murmur sering menghasilkan suara dengan nada yang lebih tinggi.

Tabel 1. Jenis-jenis jantung abnormal/murmur

\begin{tabular}{|c|l|l|}
\hline No & \multicolumn{1}{|c|}{ Nama suara jantung } & \multicolumn{1}{c|}{ Penjelasan } \\
\hline 1 & Acute rheumatic fever & $\begin{array}{l}\text { Demam rematik akut, penyakit peradangan akut yang } \\
\text { dapat menyertai faringitis yang disebabkan oleh } \\
\text { streptococcus beta-hemolyticus grup A, cendrung } \\
\text { berulang, dan sebagai penyebab terpenting penyakit } \\
\text { jantung didapat pada anak dan dewasa muda }\end{array}$ \\
\hline 2 & $\begin{array}{l}\text { Aortic insufficiency loud } \\
\text { systolic ejection murmur, third sound }\end{array}$ & $\begin{array}{l}\text { Katup aorta tidak dapat menutup dengan sempurna } \\
\text { dengan bising yang keras waktu fase ejeksi } \\
\text { sistolik bunyi jantung ketiga }\end{array}$ \\
\hline 3 & $\begin{array}{l}\text { Aortic stenosis opening snap } \\
\text { of aortic early systolic ejection sound }\end{array}$ & $\begin{array}{l}\text { Pembukaan katup aorta tidak sempurna dengan bunyi } \\
\text { pembukaan katup aorta pada pada fase ejeksis sistolik } \\
\text { dini }\end{array}$ \\
\hline
\end{tabular}


Tabel 1. lanjutan...

\begin{tabular}{|c|c|c|}
\hline No & Nama suara jantung & Penjelasan \\
\hline 4 & Atrial septal defect abnormal splitting of & Bunyi jantung terbelah yang abnormal \\
\hline 5 & Coarctation of aorta systolic murmur & Coartasio aorta dengan bising pada fase sistolik \\
\hline 6 & $\begin{array}{l}\text { Complet heart block slow heart rate, } \\
\text { varying first sound }\end{array}$ & $\begin{array}{l}\text { Blok jantung total dengan frekuensi jantung rendah, } \\
\text { bunyi jantung pertama bermacam-macam. }\end{array}$ \\
\hline 7 & $\begin{array}{l}\text { Mitral regurgiation holosystolic } \\
\text { murmur }\end{array}$ & Mitral regurgitasi dengan bising holosistolik \\
\hline 8 & $\begin{array}{l}\text { Mitral regurgiation late systolic } \\
\text { murmur crecendo type }\end{array}$ & $\begin{array}{l}\text { Mitral regurgitasi dengan bising diakhir sistolik tipe } \\
\text { crescendo }\end{array}$ \\
\hline 9 & $\begin{array}{l}\text { Mitral regurgiation mid systolic click } \\
\text { and late systolic murmur }\end{array}$ & $\begin{array}{l}\text { Mitral regurgitasi dengan bunyi klik ditengah sistolik dan } \\
\text { bising diakhir sistolik }\end{array}$ \\
\hline 10 & $\begin{array}{l}\text { Mitral regurgiation systolic murmur, } \\
\text { crescendo type }\end{array}$ & Mitral regurgitasi dengan bising sistolik tipe crescendo \\
\hline 11 & $\begin{array}{l}\text { Mitral regurgiationand mitral stenosis } \\
\text { all sound features of mitral stenosis and } \\
\text { mitral regurgitation }\end{array}$ & $\begin{array}{l}\text { Mitral regurgitasi dan mitral stenosis dengan } \\
\text { menonjolkan semua bunyi semua bunyi mitral stenosis } \\
\text { dan mitral regurgitasi }\end{array}$ \\
\hline 12 & $\begin{array}{l}\text { Mitral regurgiattion systolic } \\
\text { murmur, hight piched and } \\
\text { blowing type }\end{array}$ & $\begin{array}{l}\text { Mitral regurgitasi dengan bising sistolik } \\
\text { tipe hight piched dan blowing }\end{array}$ \\
\hline 13 & $\begin{array}{l}\text { Mitral regurgitation systolic } \\
\text { Murmur }\end{array}$ & Mitral regurgitasi dengan bising sistolik \\
\hline 14 & MItral regurguition third heart sound & Mitral stenosis dengan bunyi jantung Ketiga \\
\hline 15 & Mitral stenosis accentuated first & $\begin{array}{l}\text { Mitral stenosis dengan menonjolkan bunyi jantung } \\
\text { pertama }\end{array}$ \\
\hline 16 & Mitral stenosis opening snap & Mitral stenosis dengan opening snap \\
\hline 17 & $\begin{array}{l}\text { Mitral stenosis presystolic } \\
\text { Murmur }\end{array}$ & Mitral stenosis dengan bising pansistolik \\
\hline 18 & Mitral stenosis short middiastolic & $\begin{array}{l}\text { Mitral stenosis dengan tengah diastolic } \\
\text { yang singkat }\end{array}$ \\
\hline 19 & $\begin{array}{l}\text { Patent ductus arteriosus } \\
\text { continuous machinery murmur }\end{array}$ & $\begin{array}{l}\text { bising khas seperti sebuah } \\
\text { kereta api memasuki terowongan }\end{array}$ \\
\hline 20 & $\begin{array}{l}\text { Pulmonary stenosis harsh systolic } \\
\text { ejection murmur }\end{array}$ & $\begin{array}{l}\text { Pulmonary dengan bising ejeksi sistolik } \\
\text { yang keras }\end{array}$ \\
\hline 21 & $\begin{array}{l}\text { Right bundle branch block of first } \\
\text { sound }\end{array}$ & $\begin{array}{l}\text { Right bundle branch blok dengan bunyi } \\
\text { jantung pertama }\end{array}$ \\
\hline 22 & $\begin{array}{l}\text { Systemic hypertension } \\
\text { accentuated second sound }\end{array}$ & $\begin{array}{l}\text { Hipertensi sistemik dengan menonjolkan } \\
\text { bunyi jantung kedua }\end{array}$ \\
\hline 23 & $\begin{array}{l}\text { Tricuspid regurgitation } \\
\text { holosystolic murmur }\end{array}$ & Triscupidal regurgitasi dengan bising holosistolik \\
\hline 24 & $\begin{array}{l}\text { Ventricular sepatal defect } \\
\text { continuous murmur }\end{array}$ & $\begin{array}{l}\text { Ventrikel septal defek dengan bising yang } \\
\text { bersifat kontinyu }\end{array}$ \\
\hline
\end{tabular}

\section{3 spektrum Daya}

Salah satu komponen yang dapat diambil dari isyarat adalah spektrum frekuensinya dengan cara mentransformasikan suatu isyarat dari kawasan waktu ke kawasan frekuensi sehingga akan diperoleh sekumpulan informasi tentang frekuensi yang terkandung dalam isyarat tersebut, transformasi yang digunakan adalah transformasi Fourier.

Mendapatkan spektrum frekuensi dari isyarat suara jantung dapat dilakukan dengan menggunakan transformasi Fourier tetapi menghitung secara langsung menggunakan FFT tidak efisien karena disebabkan waktu komputasi yang akan menjadi sangat besar. Oleh karena itu digunakan metode untuk mendapatkan spektrum frekuensi isyarat yaitu perhitungan estimasi spektrum daya. 
Rapat spektral memiliki sifat yang acak yang berarti tidak periodis maka spektrum isyarat dilandasi analisis Fourier (untuk isyarat periodis) yang disebut proses acak karena periodis dengan periode dari -8 hingga 8 . Maka bila komponen frekuensi semula adalah $n=n 2 p f_{0}=n 2 p / T$ dengan T adalah 8 dan $f_{0}$ adalah 0 . Nilai koefisien yang sebelumnya dapat ditulis,

$$
\begin{aligned}
& C_{n}=\frac{1}{T} \int_{-\frac{T}{2}}^{\frac{\pi}{2}} x(t) \cdot e^{-j z p n f} f_{n} t d t \quad \text {, menjadi } \\
& x(f)=\lim _{n \rightarrow \infty} \frac{1}{T} \int_{-\frac{T}{2}}^{\frac{\pi}{2}} x(t) \cdot e^{-j 2 p m / t t d t}
\end{aligned}
$$

\subsection{Periodogram Metode Welch}

Metode ini pertama sekali dikemukakan oleh Welch (1967). Isyarat masukan dibagi menjadi segmen-segmen yang pendek dan perhitungan periodogram dilakukan berdasarkan perhitungan FFT, dengan demikian untuk mencari estimasi spektrum daya dapat dilakukan dengan perhitungan yang lebih efisien. Setiap segmen data dimodifikasi dengan mengalikan pada suatu fungsi jendela (window), sebelum dilakukan perhitungan periodogram. Selanjutnya periodogram yang telah dimodifikasi ini dirata-ratakan dan akan menghasilkan estimasi spektrum yang lebih baik.

Untuk data $x(n), 0 \leq i \leq K$, dibagi menjadi $K$ segmen dengan panjang masingmasing adalah $M$, sehingga $N=K M$, maka diperoleh $x^{(i)}(n)=x(n+i M-M)$, untuk $0 \leq$ $n \leq M-1$ dan $1 \leq i \leq K$, jadi perhitungan untuk $K$ sampel periodogram adalah:

$$
f_{M}^{(0)}(f)=\frac{1}{M U}\left|\sum_{n=0}^{M-1} x^{n}(n) w(n)\left(e^{-j n f f n T}\right)\right| \text {, dengan } U=\frac{1}{M} \sum_{n=0}^{M-1} w^{2}(n)
$$

sedangkan estimasi spektrum daya dinyatakan dengan

$$
\hat{P}_{x}(f)=\frac{1}{k} \sum_{k=0}^{k_{k}} J_{M}^{(0)}(f) \text { dan nilai varianginya } \quad \hat{P}_{x}(f) \approx \frac{1}{K} \vec{P}_{x}^{2}(f)
$$

Estimasi akan mendekati nilai sebenarnya jika $K$ sangat besar, ini berarti jumlah periodogram dibuat sebanyak mungkin namun resolusi frekuensi yang dihasikan menjadi turun. Pada persamaan (4) segmen data saling bebas dan untuk mendapatkan nilai yang lebih baik maka bingkai (frame) data diatur saling bertumpukan (overlap). Untuk $N$ sampel data deretan masukan $x(n)$ dipecah ke dalam segmen-segmen dengan panjang $M$ data dimulai dengan $D$ bagian data, dengan kata lain segmen-segman data tersebut akan saling bertumpukan sepanjang $D$ data. Jika segmen pertama adalah, dengan $n=0,1, \ldots, M-1$ maka secara umum segmen berikutnya adalah:

$$
x_{i+1}(n)=x(n, \text { untuk } i=0,1, \ldots, K-1 \text { dan } N=0,1, \ldots, M-1
$$

Pada persamaan (11) terlihat bahwa akan terdapat $K$ segmen dari seluruh panjang data $N$, sehingga panjang total data $N$ adalah:

$$
N=(R-1)
$$


Agar dapat diproses secara langsung dengan FFT maka besar $M$ dipilih angka kelipatan dua $\left(2^{\mathrm{n}}\right)$, dan untuk menekan variansi pada hasil estimasi dilakukan saling cakup (overlap) data sebesar $r=50 \%$, sedangkan perhitungan modifikasi periodogram untuk masing-masing segmen untuk $i=1,2, \ldots, K$ dan $k$ $=0,1, \ldots, M-1$ pada persamaan $(7$ dan 8$)$ adalah:

$$
y_{i}(f)-\frac{1}{M} \sum_{n=0}^{M-1} x_{i}(n) w(n)\left(a^{-j n n n h / N}\right)
$$

Sehingga periodogram atas K-segmen yang telah dimodifikasi adalah

$$
l\left(f_{k}\right)=\frac{M}{U} \mid Y_{i}\left(\left.f_{k}\right|^{2}\right.
$$

dan estimasi spektrum diperoleh dari rata-rata periodogram diatas, yaitu

$$
P_{x}(k)=\frac{1}{K} \sum_{i=1}^{K} J_{i}(k)
$$

Sedangkan nilai harapan (expected value) atas periodogram yang dimodifikasi adalah

$$
\begin{gathered}
E\left(\hat{P}_{x}(f)\right)=\frac{1}{f} \int_{-F / 2}^{F / 2} A(f) P_{n}(f-f) \\
A(f)=\frac{1}{M U}\left|\sum_{n=0}^{M-1} w(n)\left(e^{-j n g f n T}\right)\right|^{2}
\end{gathered}
$$

Sehingga nilai harapan atas estimasi adalah kerapatan PSD yang dikonvolusikan dengan kuadrat dari magnitude fungsi window.

Sampling atau pencuplikan adalah proses pengukuran besaran nilai dengan interval waktu yang sama. Isyarat sampling berisi informasi yang lengkap dan jelas selama frekuensi sampling tidak kurang dari dua kali frekuensi tertinggi dari sumber isyarat, hal ini dapat ditunjukan secara matematis jika sumber isyarat mempunyai spektrum isyarat yang dicuplik berisi semua informasi tentang sumber isyarat karena spektrum isyarat serupa dengan sumber isyarat dalam bidang $f_{s}+B$ subspektra dari isyarat tercuplik akan overlap atau saling tindih satu sama lain, dan hal ini akan mengakibatkan kehilangan informasi tentang sumber isyarat asli, kejadian ini disebut distorsi aliasing.

Kuantisasi adalah suatu proses dimana pencuplikan analog diklasifikasikan kedalam sejumlah interval kuantisasi. Tiap-tiap interval diwakili dengan suatu nilai tertentu yang disebut nilai kuantisasi, dimana nilai ini sama dengan sampling yang dibentuk pada penerjemahan. Interval kuantisasi adalah suatu interval atau jangkauan nilai yang membagi jangkauan kerja. Jangkauan kerja adalah jangkauan nilai isyarat analog yang memenuhi syarat kemudian dibagi kedalam intervalinterval kuantisasi.

\section{LANGKAH PERCOBAAN}

Estimasi spektrum daya dengan metode Welch adalah dengan menghitung DFT atas runtun $x(n)$ dan kemudian mengambil magnitude kuadrat dari hasil DFT 
tersebut. Algoritma untuk pengolahan isyarat suara jantung menggunkan metode Welch yang digunakan pada penelitian ini adalah sebagai berikut:

1. Isyarat suara jantung dibagi menjadi segmen-segmen $(x(n), K$-segmen)

2. Setiap segmen data dimodifikasi dengan mengalikan pada suatu fungsi window

$$
w(k+1)=0.54-0.46 \cos \left(2 p \frac{k}{n-1}\right)
$$

$k=0,1,2, \ldots, n-1$ dan $n=$ jumlah elemen tiap window

3. Selanjutnya dengan FFT diperoleh nilai power spektrum

4. PSD diperoleh dengan

$$
s\left(e^{i w)}=\frac{\frac{1}{n}\left|\sum_{l=1}^{n} w_{l} x_{l} \cdot e^{-j w l}\right|^{2}}{\frac{1}{n} \sum_{l=1}^{n}\left|w_{l}\right|^{2}}\right.
$$

$$
P_{x x}(w)=\frac{s\left(e^{j w}\right)}{2 p}
$$

Pada awal penelitian suara jantung diperoleh dengan menggunakan stetoskop dan penguat berlebar bidang $1 \mathrm{kHz}$ yang direkam dari suara jantung normal beberapa orang. Untuk melengkapi data murmur patologis data juga diperoleh dengan men-download suara jantung dari situs internet pada alamat http://www.sci.sdsu.edu/multimedia/heartsounds.

Analisis isyarat dengan PSD berfungsi untuk mendapatkan ekstraksi ciri dari isyarat suara jantung. PSD kemudian dilakukan analisis menggunakan metode Welch diantaranya yaitu dengan membagi isyarat menjadi segmensegmen, mengalikan pada suatu fungsi window, mentransformasikannya dan kemudian dikuadrat dan dirata-ratakan untuk memperoleh pola dalam daerah frekuensi yang dilakukan normalisasi terlebih dahulu terhadap isyarat PSD.

\section{PERCOBAAN DAN DISKUSI}

Penelitian yang telah dilakukan meliputi proses ekstraksi ciri terhadap data dengan mencari PSD isyarat suara jantung. Isyarat PSD dinormalisasi agar menghasilkan amplitudo 0 sampai 1 dan pola yang dihasilkan lebih tampak. Frekuensi di-diskritkan dengan mencuplik PSD dalam beberapa cuplikan $(20,40$, 50, 80, 100,125 dan 200 cuplikan) dengan interval pencuplikan 50, 25, 20, 12.5, 10, 8, dan $5 \mathrm{~Hz}$ sehingga daerah frekuensi yang digunakan adalah dari 0 hingga $1000 \mathrm{~Hz}$ $(20 \times 50 \mathrm{~Hz})$. Berikut di bawah ini (Gambar 3) sampai (Gambar 6) adalah contoh bentuk gelombang dan hasil pengolahan isyarat suara jantung normal.

Pada (Gambar 5) magnitude yang dihasilkan sudah bernilai antara 0 dan 1. Pada dasarnya proses normalisasi dilakukan agar nilai amplitudo maksimum sama dengan satu. Selain itu proses ekstraksi ciri juga merupakan pra-proses yang salah satunya bertujuan untuk mengurangi beban komputasi, maka pencuplikan (diskretisasi frekuensi) dari isyarat ternormalisai dilakukan dalam 20 cuplikan dengan interval pencuplikan $50 \mathrm{~Hz}$ (Gambar 6). 


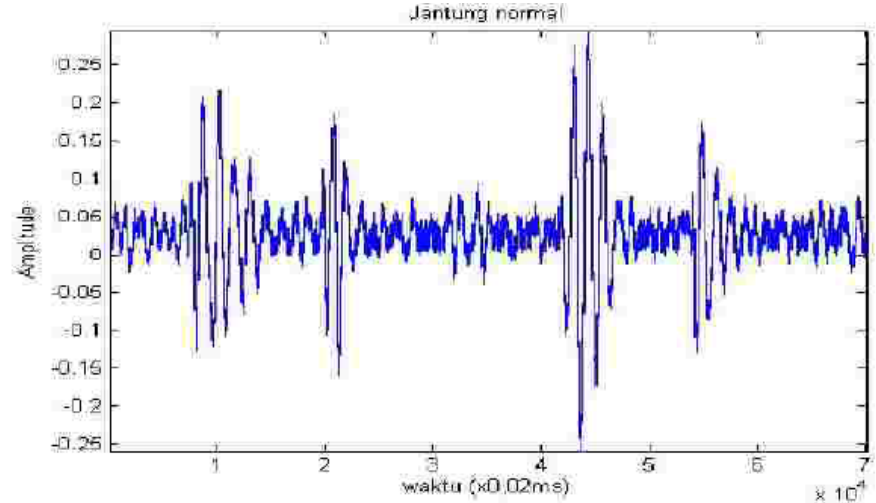

Gambar 3. Isyarat jantung normal dalam kawasan waktu

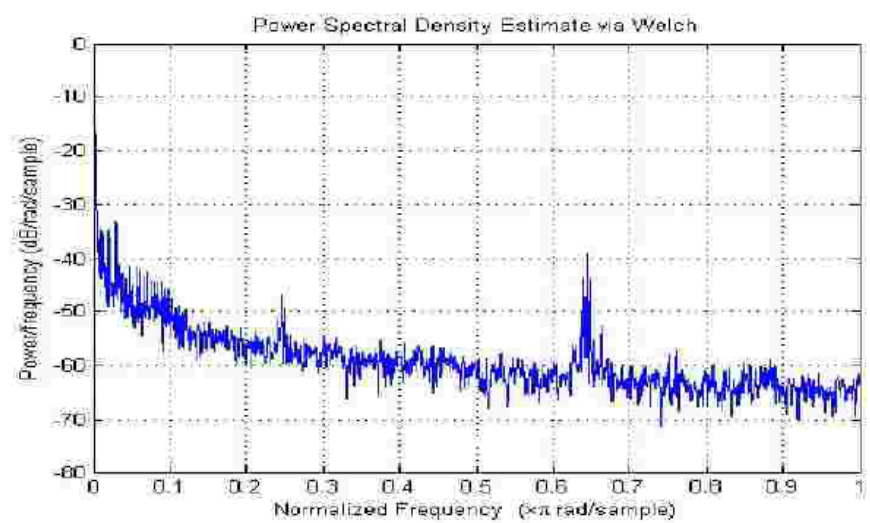

Gambar 4. Isyarat jantung normal dengan PSD metode Welch

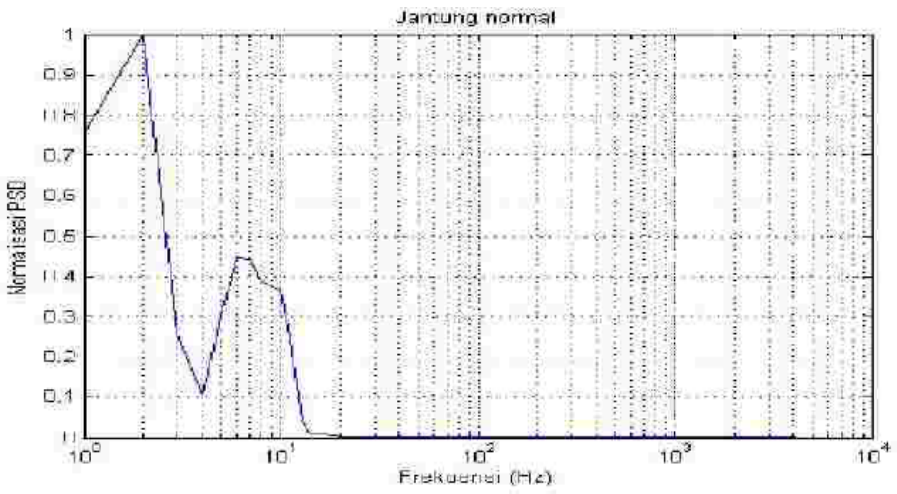

Gambar 5 Normalisasi isyarat PSD jantung normal 


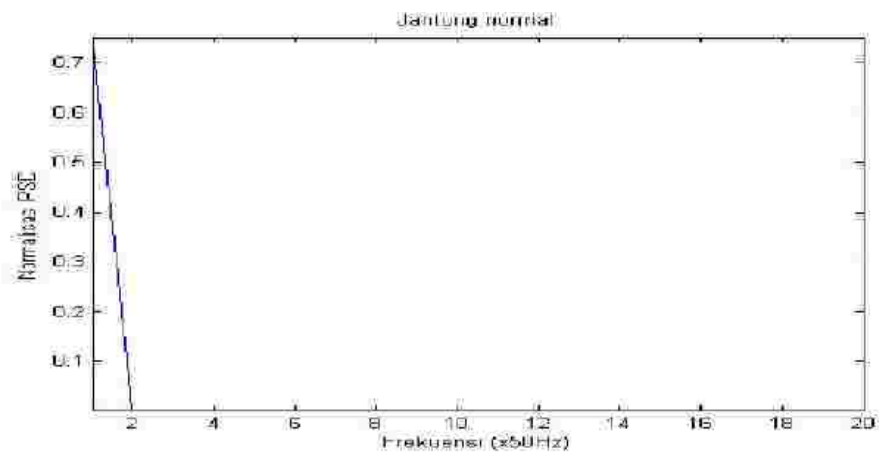

Gambar 6. Isyarat tercuplik jantung normal

Berikut di bawah ini (Gambar 7) sampai (Gambar 4.12) adalah hasil ekstraksi ciri dari isyarat jantung murmur dengan mengambil contoh isyarat jantung murmur jenis 2 atau Aortic insufficiency loud systolic ejection murmur third sound murmur seperti yang terdapat pada (Tabel 1) di atas.

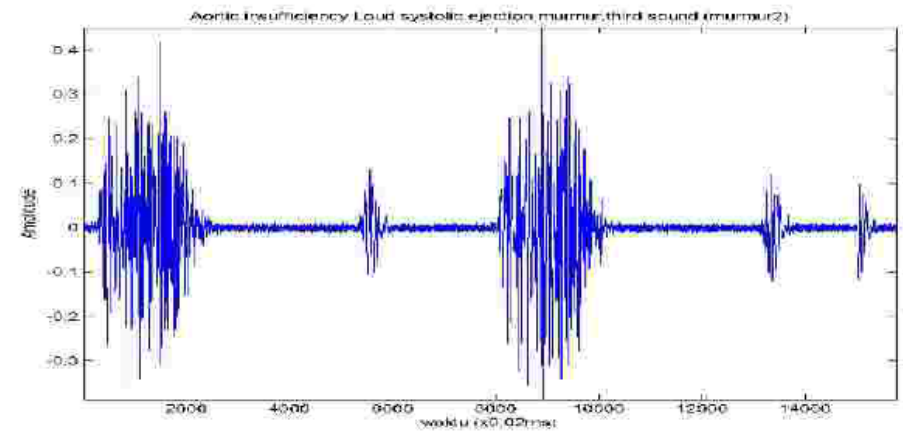

Gambar 7. Isyarat jantung murmur dalam kawasan waktu.

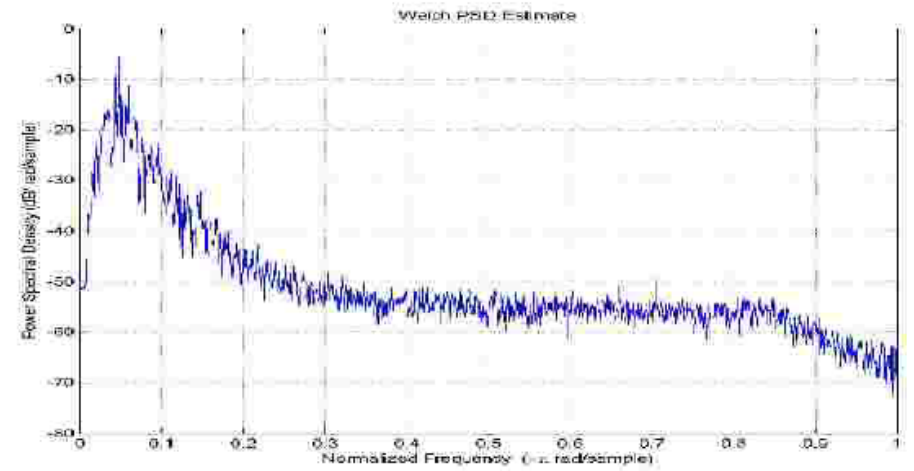

Gambar 8. Isyarat jantung murmur dengan PSD metode Welch

Pada (Gambar 9) dan (Gambar 10) sama dengan proses pada (Gambar 5) dan (Gambar 6) hanya menggunakan data isyarat jantung murmur jenis 2. 


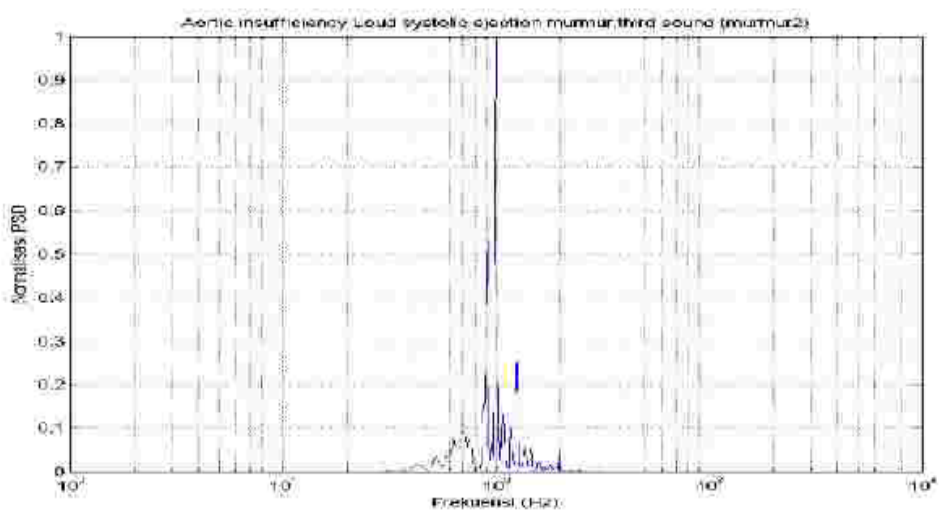

Gambar 9. Normalisasi isyarat PSD jantung murmur

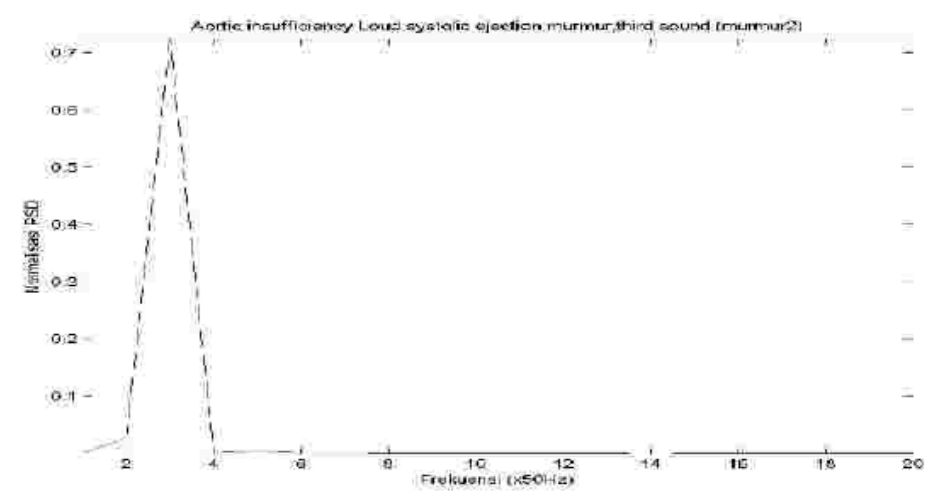

Gambar 10. Isyarat tercuplik jantung murmur

(Gambar 11) sampai (Gambar 14) berikut ini sama dengan langkah dan proses sebelumnya yaitu (Gambar 7) sampai (Gambar 10) tetapi dengan ditambahkan derau.

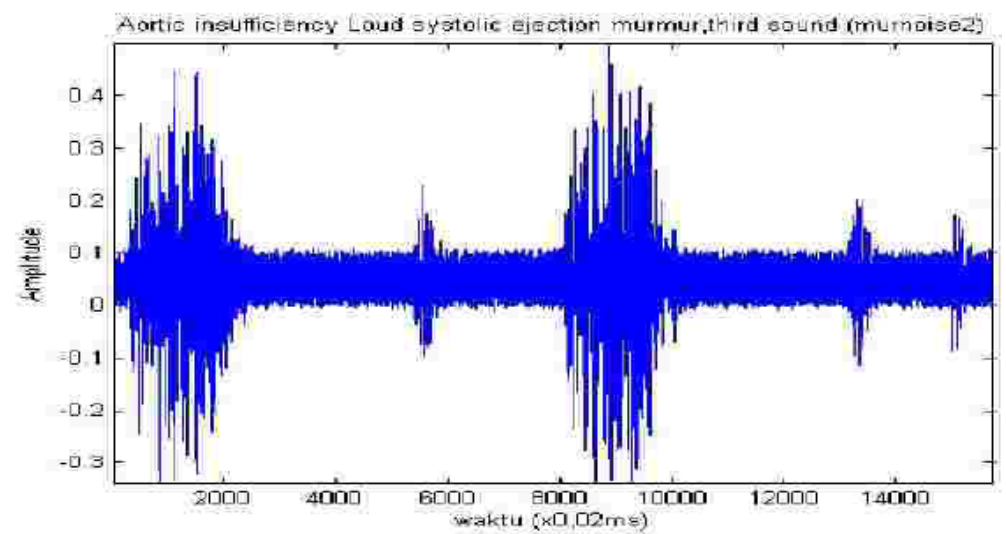

Gambar 11. Isyarat jantung murmur 2 ditambah derau. 


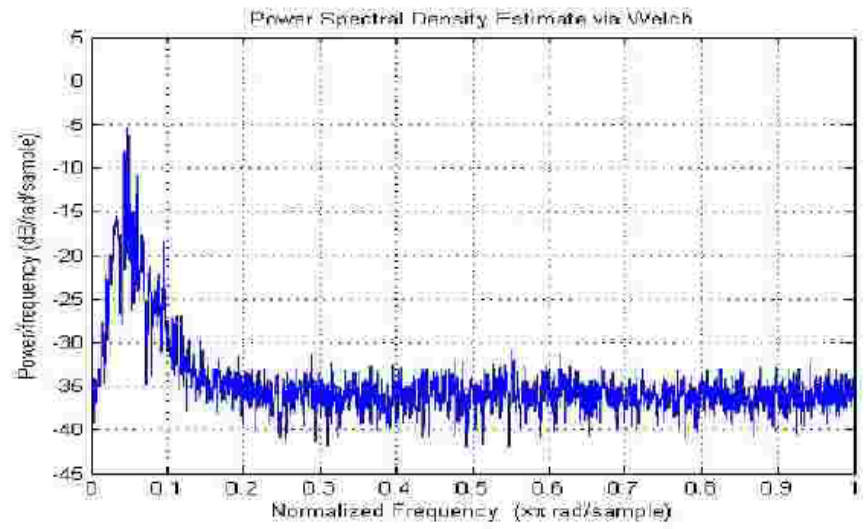

Gambar 12. Isyarat jantung murmur dengan PSD metode Welch ditambah derau

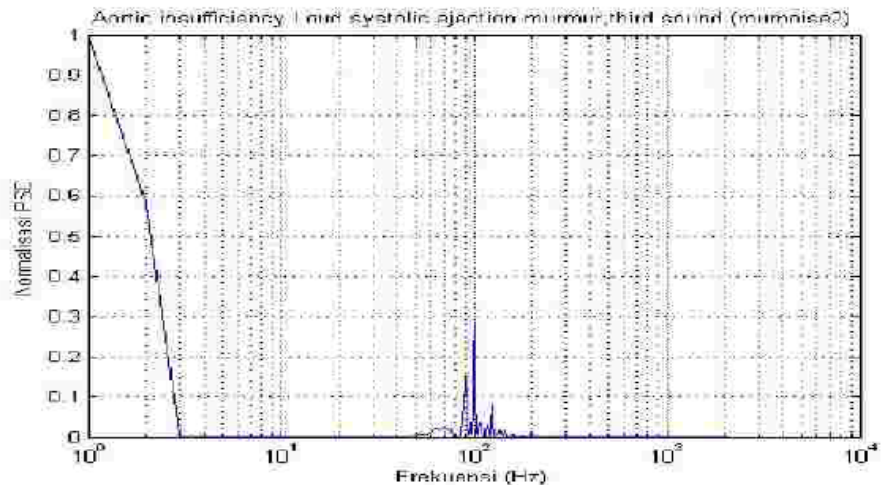

Gambar 13. Normalisasi isyarat PSD jantung murmur ditambah derau

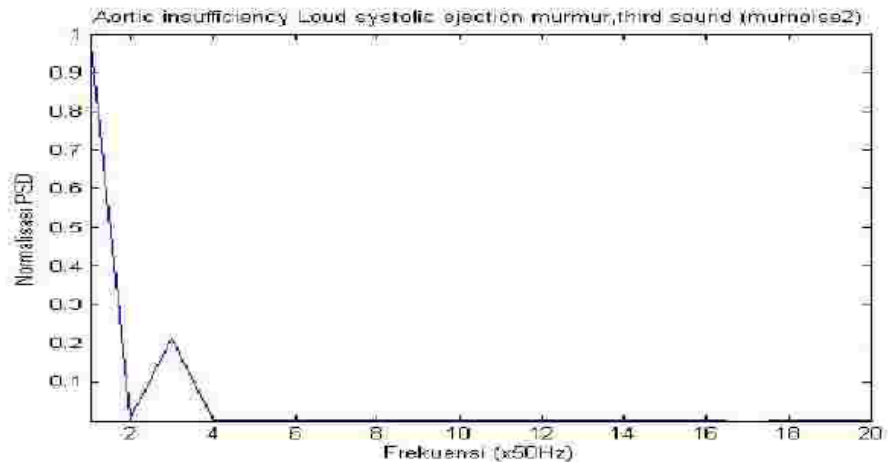

Gambar 14. Isyarat tercuplik jantung murmur ditambah derau

Untuk memperoleh hasil ekstraksi ciri, isyarat suara jantung diolah dengan PSD yang mentransformasi isyarat dalam kawasan waktu kedalam kawasan frekuensi, rapat spektral daya (PSD) diolah menggunakan metode Welch (pwelch), dan isyarat PSD yang berupa isyarat dalam kawasan frekuensi yang ternormalisasi 
dan nilai amplitudo yang bervatiasi dengan dereten matriks 4097 titik. Elemen vektor yang dihasilkan adalah:

$$
\begin{array}{lllllllllll}
0.0009 & 0.0283 & 0.7236 & 0.0016 & 0.0043 & 0.0015 & 0.0017 & 0.0003 & 0.0001 & 0.0001 & 0.0000 \\
0.0000 & 0.0000 & 0.0000 & 0.0000 & 0.0000 & 0.0000 & 0.0000 & 0.0000 & 0.0000
\end{array}
$$

Dari data diatas dapat diamati bahwa nilai yang paling besar ada pada interval ketiga, ini berarti bahwa informasi untuk isyarat ini ada disekitar frekuensi $150 \mathrm{~Hz}$. Vektor ini merupakan komponen matriks yang akan menjadi masukan bagi proses berikutnya.

\section{SIMPULAN}

Telah dilakukan ekstraksi isyarat jantung normal dan murmur dengan menggunakan rapat spektral daya atau PSD(Power Spectral Density) dengan keberhasilan mencapai $90 \%$ pada pengujian menggunakan isyarat suara jantung yang telah ditambahkan derau yang mempunyai SNR $10 \mathrm{~dB}$ pada 50 data yang sama.

Semakin besar cacah cuplikan (resolusi spektral makin tinggi) maka keberhasilan semakin meningkat sampai pada batas 125 cuplikan dimana kenaikan cacah cuplikan tidak lagi meningkatkan keberhasilan.

Makin besar derau yang mempengaruhi isyarat suara jantung (SNR makin kecil) maka keberhasilan pengujian semakin mengecil.

\section{PUSTAKA}

Anonim. (2004). Heart Sounds, diperoleh pada bulan september 2007 pada alamat: http://www.sci.sdsu.edu/multimedia/heartsounds.

Atwood, S., Stanton C., dan Storey J. (1996). Pengenalan Dasar Distrima Jantung, terjemahan, Gajah Mada University Press, Yogyakarta.

Carr J.J., and J.M. Brown. (2001). Introduction to Biomedical Equipment Technology, Prentice Hall, New Jersey.

Jumnahdi, M. (2006). Klasifikasi Isyarat Murmur Jantung Berbasis Jaringan Syaraf Tiruan, Tesis, Program Studi Teknik Elektro, Universitas Gadjah Mada, Yogyakarta.

Widodo, T.S. (2006). Akuisisi Pengolahan dan Analisis Isyarat Suara Jantung, Jurusan Teknik Elektro Universitas Gadjah Mada, Yogyakarta.

\section{DAFTAR ISTILAH}

Aorta: pembuluh darah besar yang langsung berhubungan dengan ventrikel jantung untuk mengalirkan darah keseluruh tubuh.

Aorta stenosis: pembukaan katup aorta tidak sempurna.

Aorta insufisiensi: katup aorta tidak menutup dengan sempurna sehingga terjadi aliran balik dari aorta pada fase diastolic.

Mitral stenosis: pembukaan katup mitral tidak sempurna.

Mitral regurgitasi: katup mitral tidak menutup sempurna waktu sistolik. 
Atrium septal defek: kelainan anatomi jantung akibat terjadi kesalahan pada jumlah absorbsi dan proliferasi jaringan pada tahap perkembangan pemisahan rongga atrium menjadi atrium kanan dan kiri.

Ventrikel septal defek: kelainan jantung bawaan akibat septum tidak menutup sempurna atau ada lobang yang disebut foramen ovale tidak menutup sempurna (terdapat perbedaan tekanan pada saat sistolik).

Septum: pembatas antara ruang ventrikel kiri dan kanan.

Sistolik (suara jantung 1): dihasilkan saat pengeluaran darah dari ventrikel jantung waktu jantung berkontraksi untuk diedarkan keseluruh tubuh.

Early sistolik: diawal fase.

Mid sistolik: ditengah fase.

Late sistolik: diakhir fase.

Holosistolik/pansistolik: disepanjang fase.

Diastolik (suara jantung ke-2): dihasilkan waktu relaksasi ventrikel dan menutupnya katup aorta dan pulmonalis.

Hight pitch: bising jantung yang timbul akibat darah mengalir dari ruangan bertekanan tinggi ke rendah dan melewati lobang kecil

Opening snap: sumber bunyi yang berasal dari pembukaan katup mitral atau triskupidal yang abnormal.

Blowing: bising yang terdengar bersifat meniup.

Crescendo: intensitas menaik.

Decrescendo: intensitas menurun. 